\title{
PENGARUH PERBEDAAN WARNA PIGMEN BERAS ORGANIK TERHADAP AKTIVITAS ANTIOKSIDAN
}

\author{
Effect of Pigment Color Difference in Organic Rice on Antioxidant Activity \\ Paini Sri Widyawati, Anita Maya Suteja, Thomas Indarto Putut Suseno, Pricilia Monika, \\ William Saputrajaya, Christian Liguori
}

\author{
Fakultas Teknologi Pertanian, Universitas Katolik Widya Mandala Surabaya \\ J1. Dinoyo 42-44, Surabaya 60265 \\ Email: wiwiedt@gmail.com
}

\begin{abstract}
ABSTRAK
Beras organik, meliputi beras putih varietas Jasmine, merah varietas Saodah, dan hitam varietas Jawa, banyak dibudidayakan oleh masyarakat di Indonesia, terutama daerah Sleman, D.I. Yogyakarta. Potensi ketiga jenis beras tersebut sebagai sumber antioksidan belum banyak dikaji. Oleh karena itu penelitian ini dilakukan untuk mengetahui pengaruh perbedaan pigmen pada ketiga jenis beras organik tersebut terhadap aktivitas antioksidan, khususnya kemampuan menangkap radikal bebas 2,2-difenil-1-pikrilhidrasil (DPPH) dan mereduksi ion besi. Hasil menunjukkan bahwa beras organik merah varietas Saodah paling berpotensi sebagai sumber antioksidan. Hal ini ditunjukkan dengan total fenol dan total flavonoid beras merah tertinggi dibandingkan kedua beras yang lain, masing-masing sebesar 37,93 mg GAE/g sampel $\mathrm{db}$ dan $0,85 \mathrm{mg} \mathrm{CE} / \mathrm{g}$ sampel $\mathrm{db}$. Meskipun beras organik merah mempunyai total antosianin $(0,0025 \mathrm{mg} / \mathrm{g}$ sampel $\mathrm{db})$ lebih rendah dari beras organik hitam $(0,024 \mathrm{mg} / \mathrm{g}$ sampel db). Jenis senyawa antosianin yang terdeteksi pada ketiga jenis organik ini adalah sianidin-3-glukosida yang terdeteksi pada waktu retensi 32 menit dan peonidin-3-glukosida dengan waktu retensi 37 menit. Kemampuan menangkap radikal bebas DPPH dan kemampuan mereduksi ion besi beras organik merah tertinggi, masing-masing sebesar 0,90 mg ekuivalen vit E/g sampel db dan 278,28 mg ekuivalen vit E/g sampel db.
\end{abstract}

Kata kunci: Pigmen, beras organik, aktivitas antioksidan

\begin{abstract}
Organic Rices, such as Jasmine variety white organic rice, Saodah variety red organic rice, and Java variety black organic rice, are many cultivated by farmer in Indonesia, especially Sleman area, DI Yogyakarta. The potency of three varieties of organic rice as antioxidant source hasn't been studied. Therefore this research was done to know the effect of pigment color difference in three varieties of organic rice on antioxidant activity, especially 1,1-diphenyl-2pycrylhydrazyl (DPPH) radical scavenging activity and ion reducing power. The results showed that Saodah variety red organic rice had the highest antioxidant potency because it had the highest total phenol and total flavonoid, $37.93 \mathrm{mg}$ $\mathrm{GAE} / \mathrm{g}$ sample dry base and $0.85 \mathrm{mg} \mathrm{CE} / \mathrm{g}$ sample dry base, respectively. However Saodah variety red organic rice had total anthocyanin lower than that of Java variety black organic rice, $0.0025 \mathrm{mg} / \mathrm{g}$ sample dry base and $0.024 \mathrm{mg} / \mathrm{g} \mathrm{sample}$ dry base, respectively. Anthocyanin compounds identified in three varieties of organic rice were cyanidine-3-glucoside at 32 minute time retention and peonidine -3-glucoside at 37 minute time retention. 1,1-diphenyl-2-pycrylhydrazyl (DPPH) radical scavenging activity and ion reducing power of Saodah variety red organic rice were the highest, 0.90 $\mathrm{mg}$ equivalent vitamin E/g sample dry base and $278.28 \mathrm{mg}$ equivalent vitamin $\mathrm{E} / \mathrm{g}$ sample dry base, respectively.
\end{abstract}

Keywords: Pigment, organic rice, antioxidant activity 


\section{PENDAHULUAN}

Beras organik (Oryza sativa L.) merupakan beras yang diperoleh dari padi organik yang dibudidayakan tanpa menggunakan pestisida atau bahan kimia (Balitpa, 2012). Hal ini berakibat konsumsi beras organik terus mengalami peningkatan seiring dengan meningkatnya kesadaran masyarakat akan kesehatan (Min dkk., 2012). Peningkatan kebutuhan beras organik pada tahun 2005-2009 di Indonesia telah mencapai 590.802 kuintal (PSI, 2012). Data juga menunjukkan bahwa konsumsi pangan organik, salah satunya beras organik, saat ini telah mencapai $87,1 \%$.

Peningkatan konsumsi beras organik di Indonesia disebabkan aroma dan rasa nasi dari beras organik asal Indonesia sangat berbeda dibandingkan beras organik yang berasal dari India, Thailand atau negara lainnya. Beras organik dari Indonesia mempunyai keunggulan rasa lebih enak, lebih wangi, dan pulen karena struktur tanahnya. Aromanya harum dan tahan penyimpanan. Keunggulan beras organik dari beras non organik adalah memiliki nutrisi dan mineral tinggi, kandungan glukosa, karbohidrat, dan proteinnya mudah terurai, sehingga aman dan sangat baik dikonsumsi penderita diabetes dan baik untuk program diet, mencegah kanker, jantung, asam urat, darah tinggi, dan vertigo (Anonim, 2010).

Saat ini beras organik yang tersedia dipasaran ada berbagai macam warna, diantaranya putih, hitam, coklat, dan merah. Beras organik putih varietas Jasmine, merah varietas Saodah, dan hitam varietas Jawa merupakan beras organik varietas lokal yang banyak dibudidayakan di daerah Sleman, DI Yogyakarta. Hingga saat ini potensi beras organik tersebut sebagai sumber senyawa bioaktif dan antivitas antioksidannya belum banyak dikaji. Beberapa penelitian melaporkan bahwa beras memiliki senyawa bioaktif yang tinggi, diantaranya adalah tokoferol, tokotrienol, asam ferulat, -oryzanol, dan senyawa fenolik (Chakuton, 2012). Senyawa fenolik pada beras mempunyai aktivitas antioksidan yang tinggi dan mampu menghambat radikal bebas sehingga dapat berperan sebagai anti-karsinogenik, anti-mutagenik, pengkelat logam, dan anti-mikrobial (Anli dan Vural, 2009; Proestos dkk., 2005).

Sebagian besar senyawa fenolik dalam beras berwarna adalah antosianin (Yodmanee, 2011). Antosianin merupakan senyawa fenolik yang termasuk dalam golongan flavonoid. Kadar antosianin pada beras menentukan intensitas warna gelap dan berkorelasi dengan aktivitas antioksidan (Yang dkk., 2008; Kaneda dkk., 2006). Penelitian ini dilakukan untuk mengetahui pengaruh perbedaan pigmen ketiga jenis beras organik (putih varietas Jasmine, merah varietas Saodah, dan hitam varietas Jawa) terhadap aktivitas antioksidan (menangkap radikal bebas DPPH dan mereduksi ion besi).

\section{METODE PENELITIAN}

\section{Bahan Baku}

Bahan baku yang digunakan dalam penelitian ini adalah beras organik putih varietas Jasmine, beras organik merah varietas Saodah, dan beras organik hitam varietas Jawa. Bahan tersebut diperoleh dari PT. Grahatama Semesta yang berada di J1. Dr. Wahidin No. 88, Wadas, Kabupaten Sleman, DI. Yogyakarta.

\section{Bahan Analisis}

Bahan analisis yang digunakan dalam penelitian ini adalah Follin-Ciocalteau (Merck), asam galat (Riedel-de Haen), katekin (Sigma), vitamin E (Sigma), DPPH (diphenil1-picrylhydrazy) (Aldrich), metanol (Fulltime), metanol (J.T. Baker), $\mathrm{Na}_{2} \mathrm{CO}_{3}$ (Merck), $\mathrm{NaNO}_{2}$ (Merck), $\mathrm{AlCl}_{3}$ (Merck), $\mathrm{NaOH}$ (Merck), $\mathrm{HCl}$ (Merck), $\mathrm{KCl}$ (Merck), $\mathrm{CH}_{3} \mathrm{COONa}$ (Merck), $\mathrm{NaH}_{2} \mathrm{PO}_{4}$ (Merck), $\mathrm{Na}_{2} \mathrm{HPO}_{4}$ (Merck), $\mathrm{K}_{3} \mathrm{FeCN}_{6}$ (Merck), TCA (Merck), $\mathrm{FeCl}_{3}$ (Merck), akuades (Lab. Analisa Pangan, FTP, UKWMS), akuabides (Lab. Analisa Pangan, FTP, UKWMS), dan alkohol 70\% (teknis).

\section{Preparasi Sampel}

Sampel beras organik yang digunakan adalah beras organik putih varietas Jasmine, hitam varietas Jawa, dan merah varietas Saodah. Ketiga varietas beras organik tersebut digerus dengan mortar sebelum ditambahkan metanol absolut pada saat ekstraksi.

\section{Ekstraksi Sampel}

Sampel diekstraksi berdasarkan metode Chakuton dkk. (2012). Sebanyak 28 gram sampel ditambahkan $56 \mathrm{~mL}$ metanol absolut, selanjutnya dimaserasi menggunakan shaking waterbath ada suhu $32^{\circ} \mathrm{C}$ selama 1 jam dengan kecepatan $170 \mathrm{rpm}$. Filtrat dipisahkan dari residu dengan cara disaring menggunakan kertas whatmann no.40. Selanjutnya residu yang telah dipisahkan dari filtrat diekstraksi kembali sebanyak dua kali dengan perlakuan yang sama dengan ekstraksi yang pertama. Semua filtrat yang diperoleh dicampur dan diuapkan dengan Rotary evaporator pada suhu $50^{\circ} \mathrm{C}$ dan tekanan 200 bar, sehingga didapatkan ekstrak pekat sebanyak $3 \mathrm{~mL}$. Selanjutnya ekstrak pekat ini dianalisis kadar rendemen, total fenol, total flavonoid, total antosianin, kemampuan mereduksi ion besi, dan kemampuan menangkal radikal bebas DPPH. Setiap sampel dilakukan ulangan sebanyak 3 kali.

\section{Analisis Rendemen}

Analisis rendemen dihitung berdasarkan metode Chakuton dkk. (2012). Rendemen diperoleh dari perbandingan berat ekstrak dengan berat sampel basis kering. 


\section{Analisis Total Fenol}

Total fenol dianalisis berdasarkan metode Sahreen dkk. (2010). Sebanyak 0,5 mL ekstrak encer beras organik putih, 0,05 mL ekstrak encer beras organik merah, dan $0,1 \mathrm{~mL}$ ekstrak encer beras organik hitam yang diperoleh dengan mengambil $0,5 \mathrm{~mL}$ ekstrak pekat diencerkan 2,5 mL ditambahkan $1 \mathrm{~mL}$ Folin Ciocalteu 10\% dalam labu takar 10 $\mathrm{mL}$, lalu dihomogenkan dan didiamkan selama 3-5 menit. Selanjutnya ditambahkan $2 \mathrm{~mL} \mathrm{Na}_{2} \mathrm{CO}_{3} 7.5 \%$ dan akuades hingga $10 \mathrm{~mL}$ dan dihomogenkan kembali. Absorbansi sampel diukur pada $=760 \mathrm{~nm}$ setelah 30 menit diruang gelap. Total fenol dinyatakan dengan mg ekuivalen asam galat (GAE)/ gram sampel basis kering.

\section{Analisis Total Flavonoid}

Total flavonoid dianalisis berdasarkan metode Sahreen dkk. (2010). Sebanyak 0,5 mL ekstrak encer beras organik putih, 0,2 mL ekstrak encer beras organik merah, dan $0,2 \mathrm{~mL}$ ekstrak encer beras organik hitam yang diperoleh dengan mengambil 0,5 mL ekstrak pekat diencerkan 2,5 mL dimasukkan dalam labu takar $10 \mathrm{~mL}$ ditambahkan $0,15 \mathrm{~mL}$ $\mathrm{NaNO}_{2} 5 \%$ dan $4 \mathrm{~mL}$ akuades, lalu didiamkan selama 5 menit. Kemudian ditambahkan 0,3 $\mathrm{mL} \mathrm{AlCl}_{3} 5 \%$ dan didiamkan selama 6 menit. Selanjutnya ditambahkan $2 \mathrm{~mL} \mathrm{NaOH} \mathrm{0,1M}$ dan akuades hingga tanda. Pengukuran absorbansi pada $=510 \mathrm{~nm}$. Total flavonoid dinyatakan dengan $\mathrm{mg}$ ekuivalen $(+)$-katekin (CE)/gram sampel basis kering.

\section{Analisis Total Antosianin}

Total antosianin dianalisis berdasarkan $\mathrm{pH}$ differensial metode Lee dkk. (2005). 4 mL larutan $\mathrm{pH} 1$ dan $\mathrm{pH}$ 4,5 dimasukan dalam masing-masing tabung reaksi yang berbeda dan ditambahkan ekstrak pekat beras organik (1 mL beras putih, $1 \mathrm{~mL}$ beras merah dan $0.5 \mathrm{~mL}$ beras hitam). Absorbansi sampel dilakukan pada $530 \mathrm{~nm}$ dan $700 \mathrm{~nm}$ setelah 15 menit. Total antosianin dinyatakan dalam mg ekuivalen sianida-3glukosida/g sampel basis kering.

\section{Analisis Profil Antosianin}

Profil senyawa fenolik dan antosianin ditentukan dengan HPLC (Shimadzu, Japan) yang dilengkapi dengan detektor FID. Kondisi GC-MS sebagai berikut : Kolom C18 acclaim $120,2,2 \mu \mathrm{m}$ analytical $(2,1 \times 150 \mathrm{~mm})$. Eluen terdiri atas A : $10 \%$ asam format, B : $10 \%$ asam format, $22,5 \%$ metanol, dan 22,5\% asetonitril. Laju alir : $0,475 \mathrm{~mL} / \mathrm{min}$, Volume injeksi : $2 \mu \mathrm{L}$, Try temperature : $4^{\circ} \mathrm{C}$, Suhu kolom : $35^{\circ} \mathrm{C}$. Deteksi : Absorbansi visibel pada panjang gelombang $520 \mathrm{~nm}$. Tekanan : 6700-7400 Psi secara gradien. Kondisi Gradien :
Tabel 1. Kondisi pengujian profil antosianin menggunakan kromatografi cair kinerja tinggi (HPLC)

\begin{tabular}{cccc}
\hline $\begin{array}{c}\text { Waktu } \\
(\text { Menit })\end{array}$ & $\begin{array}{c}\text { Pelarut A } \\
(\%)\end{array}$ & $\begin{array}{c}\text { Pelarut B } \\
(\%)\end{array}$ & Kondisi \\
\hline 0 & 91 & 9 & Isokratik \\
12 & 91 & 9 & Gradien \\
25 & 65 & 35 & - \\
25 & 50 & 50 & Perubahan tahap \\
30 & 50 & 50 & - \\
30 & 91 & 9 & Perubahan tahap \\
35 & 91 & 9 & Keseimbangan \\
\hline
\end{tabular}

Senyawa bioaktif yang terekstrak dari beras organik diencerkan dengan $0.01 \%$ pelarut $\mathrm{HCl}$-metanol. Larutan ekstrak disaring dengan syringe filter diameter $13 \mathrm{~mm}, 0.2$ um, PTFE Whatman, selanjutnya diinjeksikan ke dalam GC-MS. Konsentrasi antosianin dalam ekstrak didentifikasi dengan membandingkan waktu retensi dan spektra UV dari senyawa sianidin glukosidase sebagai senyawa standar.

\section{Analisis Kemampuan Menangkap Radikal Bebas DPPH}

Kemampuan menangkap radikal bebas DPPH dianalisa berdasarkan metode Sompong dkk. (2011). Sebanyak $3 \mathrm{~mL}$ larutan DPPH (4 mg/100 ml) dimasukkan dalam tabung reaksi dan ditambahkan $75 \mu \mathrm{L}$ ekstrak encer beras organik putih, $15 \mu \mathrm{L}$ ekstrak encer beras organik merah, dan $15 \mu \mathrm{L}$ ekstrak encer beras organik hitam yang diperoleh dengan mengambil 0,5 mL ekstrak pekat diencerkan 2,5 mL. Selanjutnya sampel dihomogenkan dan diukur absorbansinya pada $=515 \mathrm{~nm}$ setelah 30 menit diinkubasi. Kemampuan menangkap radikal bebas DPPH dinyatakan $\mathrm{mg}$ ekuivalen vitamin E/g sampel basis kering.

\section{Analisis Kemampuan Reduksi Ion Besi}

Kemampuan mereduksi ion besi dianalisis berdasarkan metode Oyaizu (1986). Sebanyak $2.5 \mathrm{~mL}$ buffer fosfat $\mathrm{pH} 6.6$ dan $2.5 \mathrm{~mL} \mathrm{~K}_{3} \mathrm{Fe}(\mathrm{CN})_{6}$ dimasukan dalam tabung reaksi dan ditambahkan 0,5 mL ekstrak encer beras organik putih, $0,1 \mathrm{~mL}$ ekstrak encer beras organik merah, dan $0,1 \mathrm{~mL}$ ekstrak encer beras organik hitam yang diperoleh dengan mengambil $0,5 \mathrm{~mL}$ ekstrak pekat diencerkan 2,5 mL. Campuran dihomogenkan dan diinkubasi pada suhu $50^{\circ} \mathrm{C}$ selama 20 menit. Selanjutnya campuran ditambahkan 2,5 mL TCA $10 \%$ dan disentrifugasi pada 3000 rpm selama 10 menit. Sebanyak 2,5 mL supernatan ditambahkan dengan 2,5 $\mathrm{mL}$ akuabides dan $0,5 \mathrm{~mL} \mathrm{FeCl}_{3}$ $0,1 \%$, lalu dihomogenkan dan diukur absorbansinya pada $=700 \mathrm{~nm}$. Kemampuan mereduksi ion besi dinyatakan $\mathrm{mg}$ ekuivalen vitamin $\mathrm{E} / \mathrm{g}$ sampel basis kering. 


\section{HASIL DAN PEMBAHASAN}

\section{Rendemen}

Beras organik mengandung sejumlah senyawa fitokimia yang dapat diekstrak dengan pelarut yang mempunyai tingkat kepolaran yang sesuai. Pada penelitian ini digunakan metanol sebagai pelarut sebab metanol sangat efektif mengekstraksi senyawa fenolik sehingga dihasilkan rendemen dan aktivitas antioksidan yang tinggi pada beras (Chakuton dkk., 2012), daun spesies etlingera (Chan dkk., 2007), daun mulberry (Arabshahi-Delouee dan Urooj, 2007; Yen dkk., 1996), dan daun beluntas (Widyawati dkk., 2012).

Beberapa senyawa fitokimia yang dapat terekstrak oleh metanol meliputi gula, asam amino, dan glikosida (Houghton dan Raman, 1998), fenolik dengan berat molekul rendah dan tingkat kepolaran sedang (Lin, Y. dkk., 2009), flavonoid aglikon (Dehkharghanian dkk., 2010), antosianin, terpenoid, saponin, tanin, santosilin, totarol, kuasinoid, lakton, flavon, fenon, dan polifenol (Cowan, 1999).

Kadar senyawa fitokimia yang terekstrak oleh pelarut dinyatakan sebagai rendemen, yang terdiri atas oleoresin dan minyak atsiri. Rendemen yang diperoleh dari ekstraksi ketiga varietas beras organik ditunjukkan pada Gambar 1. Rendemen tertinggi diperoleh dari ekstrak beras organik putih $(10,62 \pm 0,33 \%)$ dan terendah ada pada ekstrak beras organik merah yaitu sebesar $(9,92 \pm 0,53 \%)$. Beras putih mempunyai rendemen tertinggi diduga disebabkan beras putih mempunyai aleuron yang paling rendah dibandingkan kedua jenis beras lain, sehingga dimungkinkan senyawa non fenolik yang bersifat polar ikut terekstrak. Dugaan ini dikuatkan oleh Khalekuzzaman dkk. (2006) bahwa senyawa pigmen pada sampel beras biasanya terikat pada lapisan aleuron.

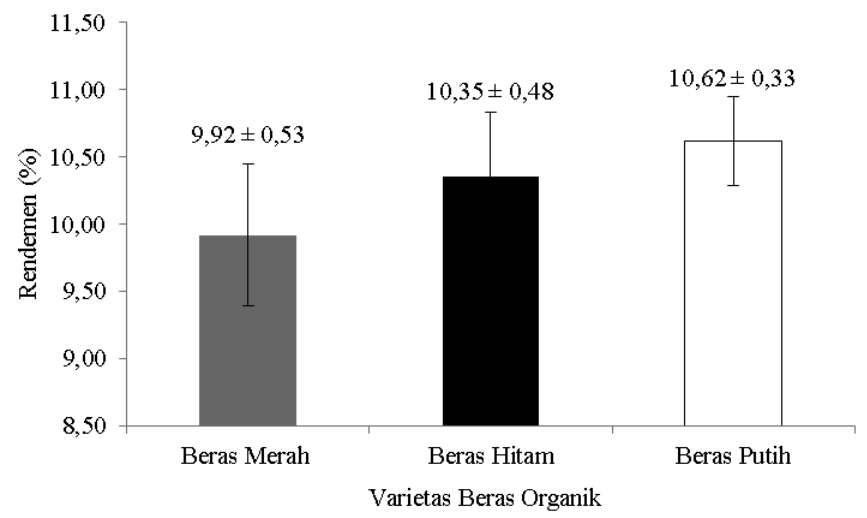

Gambar 1. Rendemen dari ketiga ekstrak beras organik

\section{Total Fenol}

Analisis total fenol dilakukan untuk mengetahui kadar senyawa bioaktif, yang berpotensi sebagai antioksidan. Senyawa fenolik yang ada dalam beras, meliputi asam galat, asam prokatekuat, asam p-hidroksi bensoat, guaiakol, p-kresol, o-kresol, dan 3,5-silenol (Vichapong dkk., 2010). Kemampuan senyawa fenolik mendonorkan elektron/atom hidrogen kepada ion molibdat (V) menjadi ion molibdat (III) dan pengompleksan ion molibdenum pada reagen Folin-Ciocalteau sehingga terbentuk larutan berwarna biru merupakan dasar pengujian total fenol. Oleh karena itu semakin banyak senyawa fenolik yang dapat mendonorkan elektron/atom hidrogen berakibat semakin tinggi intensitas warna biru yang terbentuk.

Gambar 2 menunjukkan bahwa beras merah memiliki total fenol tertinggi $(37,93 \pm 0,98 \mathrm{mg}$ GAE/g sampel basis kering) dibandingkan kedua varietas beras yang lain. Hal ini berarti senyawa fenolik pada ekstrak beras merah lebih berpotensi mendonorkan elektron atau atom hidrogen. Senyawa fenolik pada beras biasanya ada pada aleuron dan bran, sehingga adanya penyosohan pada beras putih menyebabkan total fenol beras putih terendah (Chakuton dkk., 2012). Vichapong dkk. (2010) menyatakan bahwa senyawa fenol yang terdapat pada beras berpigmen jauh lebih besar dibandingkan dengan beras tanpa pigmen. Khalekuzzaman dkk. (2006) menginformasikan bahwa senyawa pigmen pada sampel beras terikat pada lapisan aleuron. Sutharut dan Sudarat (2012) menyebutkan bahwa beras berwarna (merah dan hitam) lebih banyak mengandung antosianin dan senyawa fenolik lain dibandingkan beras putih. Muntana dan Prasong (2010) menyatakan bahwa beras hitam dan merah merupakan sumber potensial senyawa fenolik.

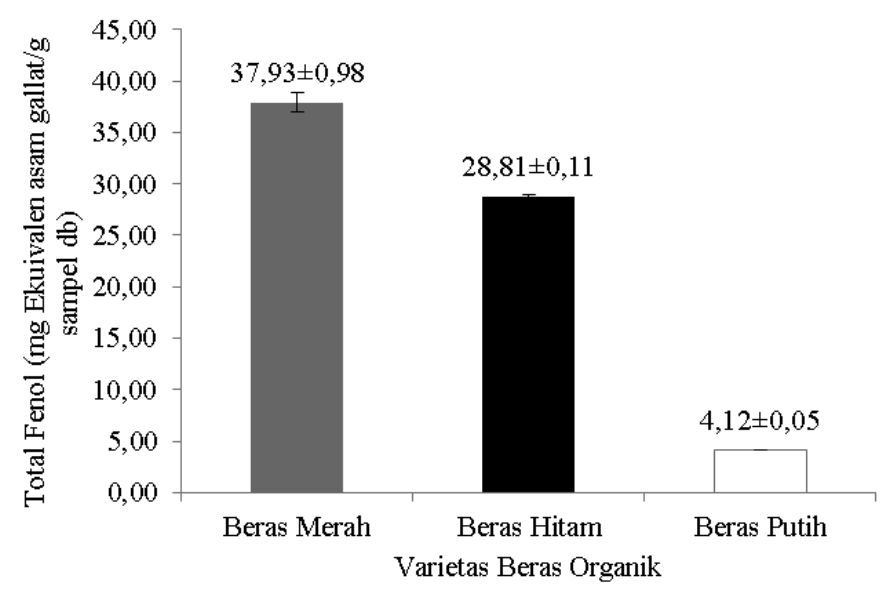

Gambar 2. Total fenol dari ketiga ekstrak beras organik

\section{Total Flavonoid}

Flavonoid merupakan salah satu senyawa fenolik terbesar kelompok benzo--piron dengan struktur umum difenilpropan (C6-C3-C6) terdiri dari 2 (dua) cincin aromatis yang dihubungkan oleh 3 (tiga) atom karbon membentuk heterosiklik teroksigenasi, ditandai dengan A, B, C (Filipiak, 
2001; Halim, 2012) yang mempunyai kapasitas antioksidan yang kuat (Aberoumand dan Deokule, 2008). Flavonoid dibedakan berdasarkan pola substitusinya, yaitu antosianin, flavon, isoflavon, flavonol, flavanon, dan flavanol (Lugasi dkk., 2003; Ghosh dkk., 2009). Pengujian total flavonoid didasarkan atas efektivitas senyawa flavonoid untuk menangkap radikal dan mengkelat ion logam (Tapas dkk., 2008). Total flavonoid pada beras organik ditunjukkan pada Gambar 3. Data menginformasikan bahwa total flavonoid tertinggi terdapat pada beras merah $(0,849 \pm 0,003 \mathrm{mg} \mathrm{CE} / \mathrm{g}$ sampel basis kering), sedangkan beras hitam memiliki total flavonoid sebesar 0,298 $\pm 0,073 \mathrm{mg} \mathrm{CE} / \mathrm{g}$ sampel basis kering dan beras putih tidak memiliki senyawa flavonoid. Total flavonoid yang terkandung dalam beras meningkat seiring peningkatan total fenol. Beras organik merah mempunyai kadar total flavonoid tertinggi karena kadar total fenolnya juga tertinggi.

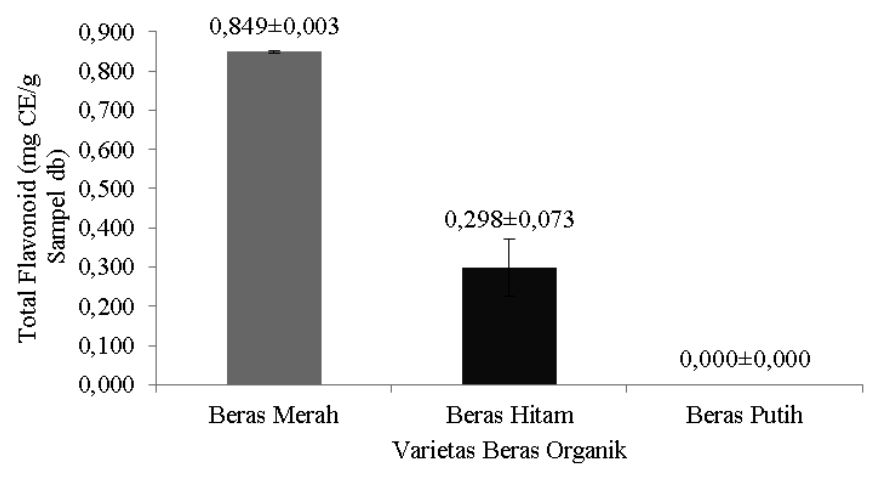

Gambar 3. Total flavonoid dari ketiga ekstrak beras organik

\section{Total Antosianin}

Antosianin merupakan bagian dari flavonoid yang berperan sebagai pigmen dan bersifat antioksidatif. Senyawa antosianin dalam bentuk sianidin-3- glukosida dan peonidin3-glukosida serta turunannya merupakan senyawa yang dapat memberikan warna pada beras (Escribano dkk., 2004; Wang dkk., 2008). Pengujian total antosianin dinyatakan dalam satuan ekuivalen sianidin-3-glukosida. Hal ini dikarenakan sekitar 93\% dari total antosianin pada beras hitam dan beras merah berbentuk sianidin-3-glukosida. Umumnya antosianin dalam beras berwarna dalam struktur prosianidin terasetilasi yang mempunyai aktivitas menangkap radikal bebas (Sutharut dan Sudarat, 2012).

Gambar 4 menunjukkan bahwa total antosianin tertinggi dimiliki beras hitam $(0,0242 \pm 0,00105 \mathrm{mg} / \mathrm{g}$ sampel dry base $)$ diikuti beras merah $(0,00247 \pm 0,00001 \mathrm{mg} / \mathrm{g}$ sampel dry base $)$, sedangkan beras putih hampir tidak memiliki antosianin. Total antosianin beras hitam paling tinggi dibandingkan kedua varietas beras yang lain, meskipun total flavonoidnya lebih rendah dari beras merah. Hal ini disebabkan antosianin merupakan flavonoid terbesar penyusun beras organik hitam. Sutharut dan Sudarat (2012) juga menginformasikan bahwa beras hitam lebih melimpah mengandung antosianin dan senyawa fenolik lain dibandingkan beras putih.

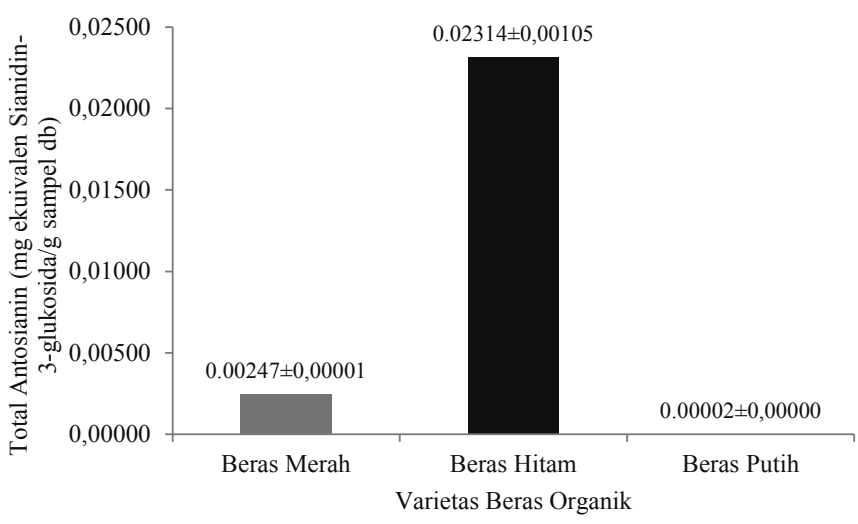

Gambar 4. Total antosianin dari ketiga ekstrak beras organik

\section{Profil Antosianin}

Profil senyawa antosianin dalam ketiga sampel tepung dan beras organik ditentukan dengan HPLC. Data profil senyawa antosianin pada ketiga jenis beras ditunjukkan pada

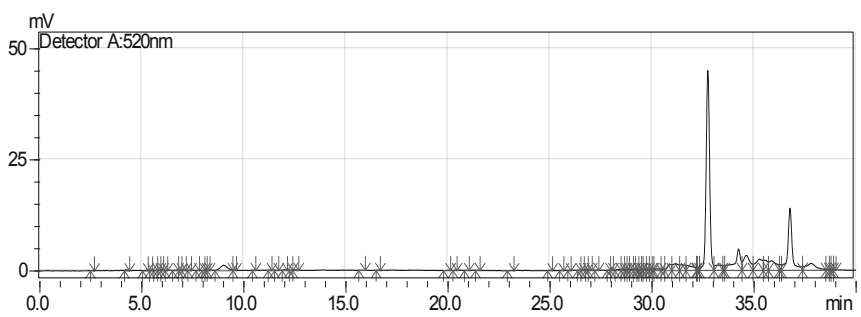

(a) Beras organik hitam

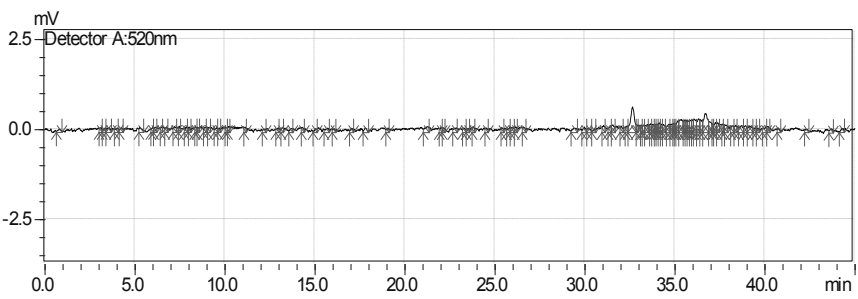

(b) Beras organik putih

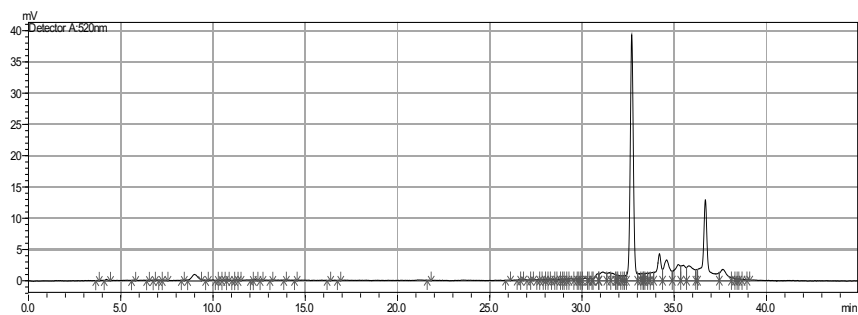

(c) Beras organik merah

Gambar 5. Profil antosianin pada ketiga ekstrak beras organic yang dideteksi dengan HPLC 
Gambar 5. Data menginformasikan bahwa senyawa antosianin yang terdapat dalam ketiga beras organik ada 2 jenis senyawa, yaitu sianidin glukosida yang terdapat pada waktu retensi 32 menit dan peonidin glukosida yang terdapat pada waktu retensi 37 menit. Kadar sianidin-3-glukosida pada beras hitam paling tinggi. Selain itu kadar sianidin glukosida pada ketiga jenis beras organik lebih tinggi dibandingkan peonidin-3glukosida. Hal ini sesuai dengan informasi Sam dkk. (2008) bahwa beras hitam mengandung sianidin 3-O-glukosidase dominan. Sompong dkk. (2011) serta Sutharut dan Sudarat (2012) juga menginformasikan bahwa beras hitam dan merah mengandung antosianin sianidin-3-glukosidasa (C3G) dan peonidin-3-glukosidasa (P3G). Muntana dan Prasong (2010) menginformasikan bahwa kadar antosianin pada beras terkait dengan pigmen warna yang dimiliki oleh beras tersebut.

\section{Kemampuan Menangkap Radikal Bebas DPPH}

1,1-difenil-2-pikrilhidrasil (DPPH) adalah radikal bebas yang mempunyai elektron tidak berpasangan pada jembatan atom nitrogen. Pelarut yang tepat digunakan adalah metanol atau buffer metanol, masing-masing tepat untuk pengujian aktivitas antioksidan dari ekstrak yang bersifat kurang polar atau non polar dan polar. Ekstrak mempunyai aktivitas antioksidan ditandai dengan kemampuannya mereduksi warna ungu dari radikal DPPH membentuk warna kuning dari senyawa DPPH-H yang dapat terdeteksi pada 515-517 nm (Sharma dan Bhat, 2009). Kemampuan senyawa fenolik mendonorkan atom hidrogen/elektron sangat ditentukan oleh struktur molekulnya dan potensial reduksinya (RiceEvans dkk., 1997). Senyawa fenolik semakin potensial sebagai pendonor elektron jika menghasilkan struktur radikal fenolik yang terstabilkan oleh adanya resonansi/delokalisasi (Widyawati dkk., 2012). Selain itu kemampuan mendonorkan elektron juga dipengaruhi oleh keberadaan gugus fungsi lain dalam cincin bensenanya.

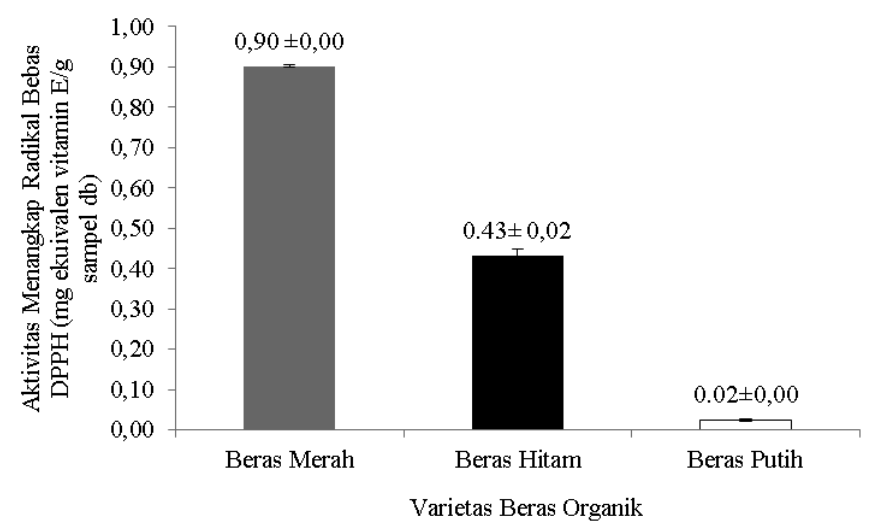

Gambar 6. Aktivitas menangkap radikal bebas DPPH dari ketiga ekstrak beras organik
Kemampuan menangkap radikal bebas DPPH dari ekstrak beras organik ditunjukkan pada Gambar 6. Data menunjukkan bahwa kemampuan penghambatan senyawa fitokimia dalam ekstrak beras organik merah paling tinggi dibandingkan kedua ekstrak beras putih dan hitam. Hal ini disebabkan beras merah mempunyai kadar total fenol dan total flavonoid tertinggi. Senyawa fenolik dan flavonoid telah terbukti mampu mendonorkan atom hidrogen kepada radikal bebas difenil pikrilhidrasil (DPPH) yang berwarna ungu sehingga terbentuk senyawa difenil pikrilhidrasin yang berwarna kuning. Beras merah dan hitam mempunyai pigmen antosianin dan senyawa fenolik jenis lain dibandingkan beras putih, sehingga potensial sebagai sumber antioksidan (Sutharut dan Sudarat, 2012; Muntana dan Prasong, 2010). Sedangkan flavonoid efektif menangkap radikal bebas karena mampu mendonokan atom hidrogen dari gugus hidroksilnya pada struktur benzo- $\gamma$-piron. Adanya peran gugus hidroksil pada posisi ortho di cincin $\mathrm{B}$, ikatan rangkap pada $\mathrm{C}_{2-3}$ yang terkonjugasi dengan gugus fungsi $\mathrm{C}_{4}$ okso serta gugus $\mathrm{OH}$ pada $\mathrm{C}_{3}$ di cincin $\mathrm{C}$, dan gugus $\mathrm{OH}$ pada $\mathrm{C}_{5}$ di cincin $\mathrm{A}$. (Amic dkk., 2003; Tapas dkk., 2008). Hasil penelitian ini sama seperti yang dilaporkan oleh Muntana dan prasong (2010) bahwa kemampuan senyawa fenolik pada ekstrak metanolik beras merah $>$ beras hitam $>$ beras putih.

\section{Reduksi Ion Besi}

Ion besi merupakan salah satu senyawa pro-oksidan. Ion $\mathrm{Fe}^{3+}$ dapat mengoksidasi substrat dan berpotensi memunculkan radikal bebas baru. Hal ini juga dikemukakan oleh Halliwell dan Gutteridge (1990) bahwa Fe mampu meningkatkan kadar radikal bebas. Antioksidan dapat berperan sebagai substrat yang akan teroksidasi lebih dulu karena sifatnya lebih reaktif. Pengujian reduksi ion besi dilakukan untuk mengetahui kemampuan antioksidan dalam beras organik untuk menetralkan ion besi.

Kemampuan mereduksi ion besi ketiga ekstrak beras organik ditunjukkan pada Gambar 7. Data menginformasikan bahwa beras merah paling berpotensi mereduksi ion besi dibandingkan beras putih dan hitam. Hal ini disebabkan beras merah mempunyai senyawa fenolik dan flavonoid yang paling tinggi yang mampu mendonorkan atom hidrogen/ elektron. Oleh karena itu kemampuan mereduksi ion besi dari ekstrak beras terkait dengan kemampuannya menangkap radikal bebas DPPH. Semakin tinggi kemampuan menangkap radikal bebasnya menyebabkan semakin tinggi pula kemampuan mereduksi ion besinya. Kemampuan mereduksi ion besi ekstrak beras merah kurang dipengaruhi oleh kadar antosianin, meskipun pigmen ini telah terbukti mempunyai aktivitas antioksidan. Sutharut dan Sudarat melaporkan bahwa beras berwarna yang mengandung antosianin dan aktivitas antioksidan lebih tinggi dari beras putih. 


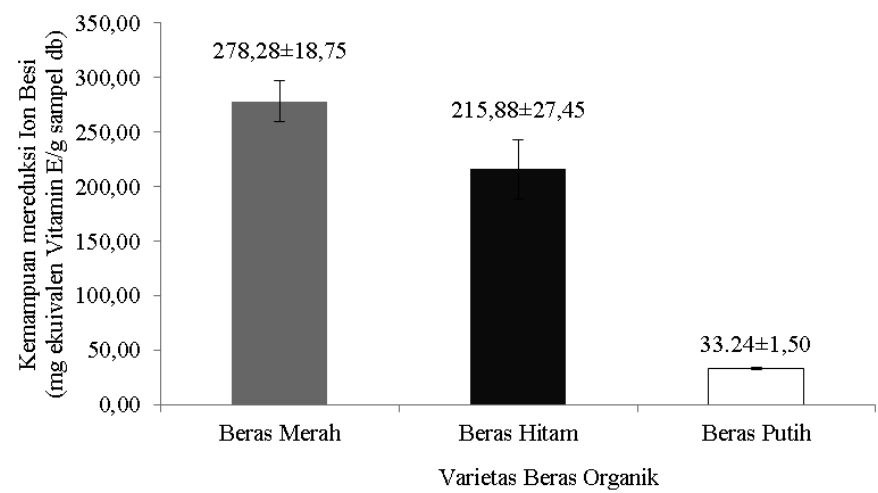

Gambar 7. Kemampuan mereduksi ion besi dari ketiga ekstrak beras organik

\section{KESIMPULAN}

Beras organik merah varietas Saodah paling berpotensi sebagai sumber antioksidan karena mempunyai kemampuan menangkap radikal bebas DPPH dan mereduksi ion besi. Hal ini disebabkan beras organik merah mempunyai total fenol dan total flavonoid tertinggi. Senyawa antosianin dalam beras merah kurang memberikan kontribusi terhadap aktivitas antioksidan. Senyawa antosianin yang terdeteksi pada ketiga beras organik adalah sianidin-3- glukosida dan peonidin-3glukosida. Senyawa sianidin-3-glukosida dominan ditemukan pada ketiga beras organik.

\section{UCAPAN TERIMA KASIH}

Ucapan terima kasih disampaikan kepada Kementrian Riset dan Teknologi (Kemanristek) atas dana penelitian yang diberikan melalui Proyek Insentif Riset Sinas tahun 2012. PT Grahatma Semesta yang berada di Jl. Dr. Wahidin No. 88, Wadas, Kabupaten Sleman, DI. Yogyakarta yang telah menyediakan sampel beras organik.

\section{DAFTAR PUSTAKA}

Aberoumand, A. dan Deokule, S.S. (2008). Comparison of phenolic compounds of some edible plants of Iran and India. Pakistan Journal of Nutrition 7(4): 582-585.

Anli, R.E. dan Vural, N. (2009). Antioxidant phenolic substances of Turkish red wines from different wine regions. Molecules 14: 289-297.

Anonim (2010). Beras premium. http://beraspremium.com [25 Agustus 2010].

Balitpa (2012). Sudah perlukah padi organik? Sukamandi.

Chakuton, K., Puangpropintag, D. dan Nakornriab, M. (2012). Phytochemical content and antioxidant activity of colored and non-colored Thai rice cultivars. Journal Asian Journal of Plant Sciences 11: 285-293.

Cowan, M.M. (1999). Plant product as antimicrobial agents. Journal of Microbiology Reviews 12(4): 564-582.

Dehkharghanian, M., Adenier, H. dan Vijayalakshmi, M.A. (2010). Analytical methods study of flavonoids in aqueous spinach extract using positive electrospray ionisation tandem quadrupole mass spectrometry. Food Chemistry 121: 863-870.

Escribano-Bail On, M.T., Santos-Buelga, C. dan RivasGonzalo, C. (2004). Anthocyanins in Cereals. Journal of Chromatography 1054(1-2): 129-141.

Filipiak, M. (2001). Electrochemical analysis of polyphenolic compounds. Analytical Sciences 17: i1667-i1670.

Ghosh, D. dan Scheepens, A. (2009). Review: vascular action of polyphenols. Molecular Nutrition and Food Research 53: 322-331.

Halim, F.Y. (2012). Identifikasi Potensi Antioksidan Minuman Coklat dari Kakao Lindak (Theobroma cacao L.) dengan Berbagai Cara Preparasi: Metode Ferric Reducing Antioxidant Power (FRAP). Skripsi, Jurusan Teknologi Pangan dan Gizi, Fakultas Teknologi Pertanian, Universitas Katolik Widya Mandala, Surabaya.

Halliwell, B. dan Gutteridge, J.M.C. (1990). Role of free radical and catalytica metal ions in human disease. American of Journal Medicine 91: 3C-4S.

Houghton, P.J. dan Raman, A. (1998). Laboratory Handbook for the Fractionation of Natural Extracts. Chapman and Hall, New York.

Kaneda, I., Kubo, F. dan Sakurai, H. (2006). Antioxidative compounds in the extracts of black rice brans. Journal of Health Science 52(5): 495-511.

Khalekuzzaman, M., Datta, K., Oliva, N., Alam, M.F., Joarder, I. dan Datta, S.K. (2006). Stable integration, expression and inheritance of the ferritin gene in transgenic elite Indica rice cultivar BR29 with enhanced iron level in the endosperm. Indian Journal of Biotechnology 5: 26-31.

Lee, J., Durst, R.W. dan Wrolstad, R.E. (2005). Determination of total monomeric anthocyanin pigment content of fruit juices, beverages, natural colorants, and wines by the $\mathrm{pH}$ differential method: collaborative study. Journal of Association of Official Analytical Chemists International 88(5): 1269-1278.

Lin, Y. H., Kuo, Y.H., Lin, Y.L. dan Chiang, W. (2009), Antioxidative effect and active component from leaves of lotus (Nelumbo nucifera). Journal of Agricultural and Food Chemistry 57: 6623-6629. 
Lugasi, A., Hóvári, J., Sági, K.V. dan Bíró, L. (2003). The role of antioxidant phytonutrients in the prevention of diseases. Acta Biologica Szegediensis 47(1-4): 119125.

Min, B., Gu, L., McClung, A.M., Bergmen, C.J. dan Chen, M.H. (2012). Free and bound total phenolic concentrations, antioxidant capacities, and profiles of proanthocyanidins and anthocyanins in whole grain rice (Oryza sativa L.) of different bran colours. Food Chemistry 133: 715-722.

Muntana, N., dan Prasong, S. (2010). Study on total phenolic contents and their antioxidant activities of thai whaite, red, and black rice bran extracts. Pakistan Journal of Biological Sciences 13(4): 170-174.

Oyaizu, M. (1986). Studies on products of browning reaction: antioxidative activities of products of browning reaction prepared from glucosamine. Japanese Journal of Nutrition 44: 307-315.

Proestos, C., Bakogianis, A., Psarianos, C., Koutinas, A.A., Kanellaki, M. dan Komaitis, M. (2005). High performance liquid chromatography analysis of phenolic substances in Greek wines. Journal of Food Control 16: 319-323.

PSI (Pertanian Sehat Indonesia). (2012). Tren konsumsi beras organik meningkat. Wacana, Edisi18 Mei 2012.

Rice-Evans, C.A., Miller, N.J. dan Paganga, G. (1997). Antioxidant properties of phenolic compounds. Trends in Plants Science 2(4): 152-159.

Sahreen, S., Khan, M.R. dan Khan, R.A. (2010). Evaluation of antioxidant activities of various solvent extracts of Carissa opaca fruits. Food Chemistry 122: 1205-1211.

Sharma, O.P. dan Bhat, T.K. (2009). Analytical methods DPPH antioxidant assay revisited. Food Chemistry 113: 1202-1205.
Sompong, R., Siebenhandl-Ehn, S., Linsberger-Martin G. dan Berghofer, E. (2011). Physicochemical and antioxidative properties of red and black rice varieties from Thailand, China, and Sri Lanka. Food Chemistry 124: 132-140.

Sutharut, J. dan Sudarat, J. (2012). Total anthocyanin content and antioxidant activity of germinated colored rice. International Food Research Journal 10(1): 215-221.

Tapas, A., Sakarkar, D.M. dan Kakde, R.B. (2008). Flavonoids as nutraceuticals: a review. Tropical Journal of Pharmaceutical Research 7(3): 1089-1099.

Vichapong, J., Sookserm, M., Srijesdaruk, V., Swatsitang, P. dan Srijaranai, S. (2010). High performance liquid chromatographic analysis of phenolic compounds and their antioxidant activities in rice varieties. LWT-Food Science Technology 43: 1325-1330.

Wang, L.S. dan Stoner, G.D. (2008). Anthocyanins and their roles in cancer prevention. Cancer Letters 269: 281290.

Widyawati, P.S., Wijaya, C.H., Hardjosworo, P.S. dan Sajuthi, D. (2012). Aktivitas antioksidan berbagai fraksi dan ekstrak metanolik daun beluntas (Pluchea indica Less). Agritech 32(3): 249-257.

Yang, D.S., Lee, K.S., Jeong, O.Y., Kim, K.J. dan Kays, S.J. (2008) Characterization of volatile aroma compounds in cooked black rice. Journal of Agricultural and Food Chemistry 56: 235-240.

Yodmanee, S., Karrila, T.T. dan Pakdeechanuan, P. (2011). Physical, chemical and antioxidant properties of pigmented rice grown in Southern Thailand. International Food Research Journal 18: 901-906. 